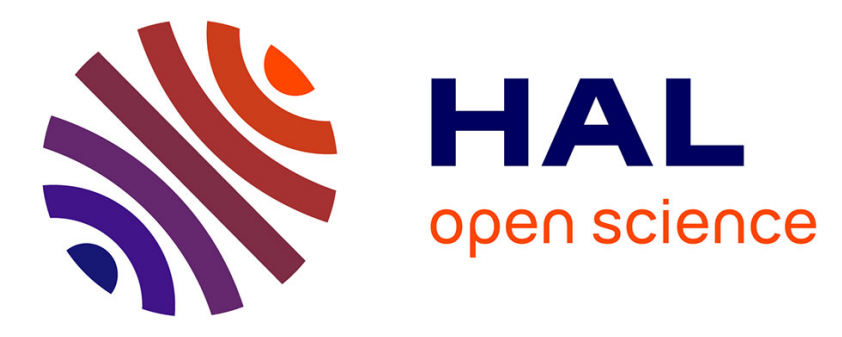

\title{
Inter-annual variation in winter distribution affects individual seabird contamination with mercury
}

Céline Albert, V. S. Bråthen, S Descamps, T Anker-Nilssen, A Cherenkov, S

Christensen- Dalsgaard, J Danielsen, K. E. Erikstad, M Gavrilo, S. A. Hanssen, et al.

\section{To cite this version:}

Céline Albert, V. S. Bråthen, S Descamps, T Anker-Nilssen, A Cherenkov, et al.. Inter-annual variation in winter distribution affects individual seabird contamination with mercury. Marine Ecology Progress Series, 2021, 676, pp.243-254. 10.3354/meps13793 . hal-03268466

\section{HAL Id: hal-03268466 https://hal.science/hal-03268466}

Submitted on 22 Nov 2021

HAL is a multi-disciplinary open access archive for the deposit and dissemination of scientific research documents, whether they are published or not. The documents may come from teaching and research institutions in France or abroad, or from public or private research centers.
L'archive ouverte pluridisciplinaire HAL, est destinée au dépôt et à la diffusion de documents scientifiques de niveau recherche, publiés ou non, émanant des établissements d'enseignement et de recherche français ou étrangers, des laboratoires publics ou privés. 


\title{
Inter-annual variation in winter distribution affects individual seabird contamination with mercury
}

C. Albert ${ }^{1} *$, V. S. Bråthen ${ }^{2}$, S. Descamps ${ }^{3}$, T. Anker-Nilssen ${ }^{2}$, A. Cherenkov ${ }^{4}$, S. ChristensenDalsgaard $^{2}$, J. Danielsen ${ }^{5}$, K. E. Erikstad ${ }^{6}$, M. Gavrilo ${ }^{7,8}$, S. A. Hanssen ${ }^{6}$, H. H. Helgason ${ }^{3}$, J. E. Jónsson $^{9}$, Y. Kolbeinsson ${ }^{10}$, Y. Krasnov ${ }^{11}$, M. Langset ${ }^{2}$, E. Lorentzen ${ }^{3}$, B. Olsen ${ }^{5}$, T. K. Reiertsen ${ }^{6}$, H. Strøm ${ }^{3}$, G. H. Systad ${ }^{2}$, G. Tertitski1 ${ }^{12}$, P. M. Thompson ${ }^{13}$, T. L. Thórarinsson ${ }^{10}$, P. Bustamante ${ }^{1,14}$, B. Moe ${ }^{2, \#}$, J. Fort ${ }^{1, \#}$

\author{
${ }^{1}$ Littoral, Environnement et Sociétés (LIENSs), UMR 7266 CNRS-La Rochelle Université, 17000 La \\ Rochelle, France \\ ${ }^{2}$ Norwegian Institute for Nature Research (NINA), 7485 Trondheim, Norway \\ ${ }^{3}$ Norwegian Polar Institute, FRAM Centre, 9296 Tromsø, Norway \\ ${ }^{4}$ Lomonosov Moscow State University, Solovetskiy Branch of White Sea Biological Station, Solovetskiy, \\ Arkhangelsk district 164409, Russia \\ ${ }^{5}$ Faroe Marine Research Institute, 110 Tórshavn, Faroe Islands \\ ${ }^{6}$ NINA, FRAM Centre, 9296 Tromsø, Norway \\ ${ }^{7}$ Association Maritime Heritage, Icebreaker 'Krassin', The Lieutenant Schmidt emb., 23 Line, Saint- \\ Petersburg 199106, Russia \\ ${ }^{8}$ National Park Russian Arctic, Archangelsk 168000, Russia \\ ${ }^{9}$ University of Iceland's Research Center at Snæfellsnes, 340 Stykkishólmur, Iceland \\ ${ }^{10}$ Northeast Iceland Nature Research Centre, 640 Húsavík, Iceland \\ ${ }^{11}$ Murmansk Marine Biological Institute, Murmansk 183010, Russia \\ ${ }^{12}$ Institute of Geography of the Russian Academy of Sciences, Moscow 119017, Russia \\ ${ }^{13}$ University of Aberdeen, School of Biological Sciences, Lighthouse Field Station, Ross-shire, Cromarty \\ IV11 8YJ, UK \\ ${ }^{14}$ Institut Universitaire de France (IUF), 75005 Paris, France \\ ${ }^{\#}$ These authors share equal authorship
}

Running page head: Albert et al.: Inter-annual variation in winter $\mathrm{Hg}$ concentrations

\begin{abstract}
Migratory seabirds are exposed to various pollutants throughout their annual cycle. Among them, mercury $(\mathrm{Hg})$ is of particular concern given its large impact on animal health. Recent studies suggest that winter is a critical period for seabirds when contamination by $\mathrm{Hg}$ can be higher than at other times of year. However, individuals within and between species can have different migration strategies that could affect their exposure. Here, we combined multi-year individual tracking data and $\mathrm{Hg}$ measurements from 6 Arctic seabird species. We investigated whether inter-annual variations in individual winter contamination with $\mathrm{Hg}$ was related to seabird fidelity to a wintering site over years. First, our results show that $\mathrm{Hg}$ concentrations above the toxicity threshold (i.e. $5 \mu \mathrm{g} \mathrm{g}^{-1}$ dry weight in feathers) were observed in variable proportions according to species (from $2 \%$ of northern fulmars to $37 \%$ of Brünnich's guillemots). Second, individuals with high fidelity to a wintering ground had more similar $\mathrm{Hg}$ concentrations among years compared to individuals with low fidelity, suggesting an effect of their migratory strategy on $\mathrm{Hg}$ contamination. Further, we found that the directional change in wintering areas among years influenced seabird $\mathrm{Hg}$ contamination, highlighting an additional effect of seabirds' winter distribution. More specifically, individuals migrating to the northwest direction of a previous wintering ground tended to be more contaminated compared those moving to eastern directions. These results confirm spatial differences in $\mathrm{Hg}$ concentration throughout the North Atlantic-Arctic and an east-west gradient increase in $\mathrm{Hg}$ concentrations. Verifying this trend will require more large-scale ecotoxicological studies at smaller spatial resolution.
\end{abstract}

Key words: Feathers $\cdot$ Pollutant $\cdot$ Migration $\cdot$ North Atlantic-Arctic $\cdot$ Biologging 


\section{Introduction}

Mercury $(\mathrm{Hg})$ is a highly toxic pollutant for humans and wildlife, causing severe health impairments, even at low concentrations (e.g. Wolfe et al. 1998, Tan et al. 2009, Dietz et al. 2019). $\mathrm{Hg}$ is naturally emitted by volcanoes or weathering of rocks (UNEP 2013), but anthropogenic activities have been responsible for an increase in $\mathrm{Hg}$ concentrations in the environment since the industrial revolution (e.g. a 3-fold increase in surface marine waters; Lamborg et al. 2014). This pollutant is very problematic in aquatic environments, where it can easily be transformed into its most toxic form (methylmercury or $\mathrm{MeHg}$ ) by microorganisms (Hsu-Kim et al. 2013). This form is the most bioavailable to biota and is incorporated into food chains, in which it biomagnifies (i.e. increase in concentration within trophic chains), making top predators the most contaminated species of their ecosystems. $\mathrm{Hg}$ is thus of major environmental concern worldwide. Its spatial distribution is highly heterogeneous at the global scale (Zhang et al. 2020): while Hg is mostly emitted at midnorthern latitudes, its physico-chemical characteristics allow it to be transported over large distances through atmospheric, oceanic or riverine currents, and $\mathrm{Hg}$ is thus redistributed unevenly across the globe (AMAP 2011, Sonke et al. 2018). For example, Dietz et al. (2000) found that polar bears (Ursus maritimus) from northwest Greenland had $\mathrm{Hg}$ concentrations $\sim 10$-fold higher than individuals from northeast Greenland. In the southern hemisphere, a negative latitudinal gradient in $\mathrm{Hg}$ concentrations has been found in 35 albatross populations (Cherel et al. 2018). Therefore, variations in the spatial distribution of top predators can lead to highly different $\mathrm{Hg}$ exposure and contamination, potentially resulting in contrasting risks for individual health (Ackerman et al. 2016, Dietz et al. 2019). Among marine top predators, seabirds show some of the highest $\mathrm{Hg}$ concentrations (Atwell et al. 1998), with deleterious effects on behavior, physiology or reproduction reported in some species and populations. For example, amongst adult male black-legged kittiwakes (Rissa tridactyla) breeding in Svalbard, individuals with the highest $\mathrm{Hg}$ concentrations were more likely to neglect their eggs (Tartu et al. 2015). Similarly, high $\mathrm{Hg}$ concentrations in birds have been related to a reduction of hatchability and clutch size (Dietz et al. 2013, Ackerman et al. 2016), in addition to a decline in breeding success and population growth rate (Goutte et al. 2014). Understanding the relationship between seabird distribution and contamination by $\mathrm{Hg}$ is therefore important for the conservation of these species, with many populations declining and deserving special attention (Croxall et al. 2012, Paleczny et al. 2015).

Seabirds are typically migratory species, many travelling hundreds to thousands of kilometers every year to reach their wintering grounds (e.g. Egevang et al. 2010, McFarlane Tranquilla et al. 2014, Frederiksen et al. 2016). However, these migratory strategies can be highly variable among individuals, conditioning their winter distribution and thus potentially their exposure to Hg. First, individuals from the same population can use contrasting wintering areas, at varying distance from their breeding colonies (Quillfeldt et al. 2010). For instance, red-legged kittiwakes (Rissa brevirostris) breeding at Saint George Island (Pribilof Islands, Bering Sea) overwinter anywhere from the Eastern Bering Sea to the Sea of Okhotsk, with higher Hg concentrations measured in individuals using southern areas (Fleishman et al. 2019). Second, individuals may or may not vary their migratory routes and destinations among years, leading to contrasting fidelity to wintering grounds among individual birds (Delord et al. 2017). Hence, species can show a tendency for high (e.g. common eider Somateria mollissima, Atlantic puffin Fratercula arctica, European shag Phalacrocorax aristotelis; Guilford et al. 2011, Petersen et al. 2012, Grist et al. 2014, Hanssen et al. 2016), low (e.g. thin-billed prion Pachyptila belcheri; Quillfeldt et al. 2010) or variable (e.g. Brünnich's guillemot Uria lomvia, common guillemot U. aalge, northern fulmars Fulmarus glacialis; Hatch et al. 2010, McFarlane Tranquilla et al. 2014, Orben et al. 2015) fidelity to their wintering ground from one year to the other. Together, these different migratory patterns and overwintering strategies may affect the long-term exposure of seabirds to $\mathrm{Hg}$ and differentially impact their health, reproduction and consequently their population dynamics (Vindenes et al. 2008). 
However, no study has previously considered the link between consistency in winter distribution and contamination with $\mathrm{Hg}$.

By combining individual tracking data with $\mathrm{Hg}$ analyses and focusing on some of the most abundant Arctic seabird species (i.e. black-legged kittiwake, Brünnich's guillemot, common eider, common guillemot, little auk Alle alle and northern fulmar), which feed at different trophic levels, we studied inter-annual fidelity to wintering grounds. We tested the hypothesis that this fidelity determines the consistency of their $\mathrm{Hg}$ contamination. More specifically, and as $\mathrm{Hg}$ contamination is closely related to diet, we first predicted that species feeding at the highest trophic levels during the non-breeding period (i.e. common guillemot and northern fulmar) have higher $\mathrm{Hg}$ concentrations than species feeding at the lowest trophic levels (i.e. black-legged kittiwake, Brünnich's guillemot, common eider and little auk). Then, we predicted that (1) seabirds with low fidelity to a wintering ground from one year to the other show more variable $\mathrm{Hg}$ contamination in comparison to those showing similar inter-annual winter distributions and (2) seabird wintering distribution affects $\mathrm{Hg}$ contamination (Renedo et al. 2020).

\section{Materials and methods}

\subsection{Species, study sites and sampling collections}

In June-July of 2014, 2015 and 2016, adult black-legged kittiwakes ( $\mathrm{n}=13$ ), Brünnich's guillemots (65), common eiders (22), common guillemots (39), little auks (6) and northern fulmars (38) were equipped for 2 or $3 \mathrm{yr}$ (details in Table S1 and Fig. S1 in the Supplement at www.intres.com/articles/suppl/m13793supp.pdf) with light level geolocators (GLS: global location sensor; geolocator models are given in Table S2 in the Supplement) during incubation and chick rearing at 17 breeding colonies from Iceland to Russia (Fig. 1). Geolocators were retrieved in each subsequent breeding season (details in Table S3 in the Supplement), and only a subsample of all tracked seabirds was analyzed for $\mathrm{Hg}$ concentrations (hereafter [Hg]) (i.e. seabirds for which we had at least 2 winters of GLS data). After retrieval, seabirds were re-equipped in order to have their winter distribution for at least 2 years. Geolocators are low-weight instruments that record ambient light levels over long time periods, and these data can later be converted into geographical locations (Wilson et al. 1992). However, the positional precision derived from light-level data is considered low (Lisovski et al. 2012) and is mostly suited for studies of large-scale movements and distribution such as seabird migrations. The distributions extracted from the geolocators deployed in 2014, 2015 and 2016 represent November 2014 to January 2015 (winter $_{t}$ ), November 2015 to January 2016 (winter ${ }_{t+1}$ ) and November 2016 to January 2017 ( winter $_{t+2}$ ), respectively (see Fig. 2).

In order to investigate individual $\mathrm{Hg}$ contamination during winter (i.e. non-breeding) periods, feathers were collected at the time of geolocator retrieval, as they are a useful tissue for this purpose (Albert et al. 2019). During the plumage synthesis (molt), a large proportion of the $\mathrm{Hg}$ accumulated in internal organs since the last molt, but also $\mathrm{Hg}$ from the current diet, is excreted into the feathers (Honda et al. 1986, Braune 1987, Agusa et al. 2005) (Fig. 2). Hence, [Hg] in feathers can be used as proxy for $\mathrm{Hg}$ accumulated by an individual between 2 molting sequences, and specifically during the non-breeding period depending on which feathers are sampled and the species' molting pattern (see Albert et al. 2019). For example, alcids and larids undergo a rapid total molt at the end of the breeding period (during September or October) resulting in the winter plumage and a partial molt (head, i.e. cheek, neck and throat in alcids, and neck and back in larids) at the end of the winter period (during March or April) resulting in the nuptial plumage (Cramp \& Simmons 1983, Gaston \& Jones 1998). Female common eiders undergo a total molt at the end of the winter period and a partial molt at the end of the breeding period (Baldassarre 2015, Goudie et al. 2020). Hence, head, back and belly feathers provide information on $\mathrm{Hg}$ contamination specifically during the winter period in alcids, black-legged kittiwakes and common eiders, respectively. Northern fulmars undergo one total 
molt per year at the end of the breeding period, lasting from mid-August to late October (Grissot et al. 2020). Recent studies indicate that $[\mathrm{Hg}]$ in fulmar body feathers reflect inter-individual variations in $\mathrm{Hg}$ contamination during the non-breeding period (e.g. Quinn et al. 2016). Therefore, body feathers (i.e., belly) were used to assess $\mathrm{Hg}$ contamination during the non-breeding period for northern fulmars.

Therefore, at the retrieval of geolocators, we collected head feathers from Brünnich's guillemots, common guillemots and little auks, and body feathers on black-legged kittiwakes (back feather), common eiders (belly feather), and northern fulmars (belly feather), representing $\mathrm{Hg}$ contamination during the preceding non-breeding period (Fig. 2). Feathers were stored in plastic bags at ambient temperature until $\mathrm{Hg}$ analyses.

\subsection{Spatial analyses}

The geolocator data were first converted into positional data by identifying the timing of twilights, using a threshold method, from which we estimated 2 daily latitudes from the length of the night and day, and 2 daily longitudes from time of apparent midnight and noon, following procedures described in Merkel et al. (2016) and Bråthen et al. (2021). Since the geolocation approach requires light to estimate seabird positions, for individuals located above $70^{\circ} \mathrm{N}$, positions could not be obtained for days or weeks around winter solstice because of an apparent absence of daylight above this latitude (details in Table S4 and Fig. S2 in the Supplement). However, these periods were relatively brief (from 0 to $12.9 \mathrm{~d}$; Table S4), enabling us to determine the wintering locations with confidence.

The timing of Arctic seabird molt and migration can vary slightly between breeding sites (Frederiksen et al. 2012, Fort et al. 2013a). Nonetheless, to allow for inter-population comparisons, and based on the knowledge about when seabirds are on their wintering ground (Fort et al. 2012, 2013a, Frederiksen et al. 2016), we homogenized the winter period within species. Therefore, we considered that seabirds were at their wintering ground from November to January for black-legged kittiwakes (Frederiksen et al. 2012), Brünnich's and common guillemots (Fort et al. 2013b, Frederiksen et al. 2016, Merkel et al. 2019), common eiders (Hanssen et al. 2016), and little auks (Fort et al. 2012). As northern fulmars have been observed returning back to their colonies as early as January in the literature (Macdonald 1980) and in our dataset, the non-breeding period was defined from November to December in this species. We then calculated a median winter position (i.e. median latitude and median longitude) for each individual for each year, to be used in further analyses.

\section{3. $\mathrm{Hg}$ analyses}

Prior to $\mathrm{Hg}$ analyses, feathers were cleaned to remove external contamination: they were plunged into a $2: 1 \mathrm{v} / \mathrm{v}$ chloroform:methanol solution for $3 \mathrm{~min}$ in an ultrasonic bath, rinsed twice in a methanol solution and dried at $45^{\circ} \mathrm{C}$ for $48 \mathrm{~h}$. For each seabird, $[\mathrm{Hg}]\left(\mu \mathrm{g} \mathrm{g} \mathrm{g}^{-1}\right.$ dry weight $\left.(\mathrm{dw})\right)$ were measured in subsamples ( 0.20-1.00 mg each) of a pool of 3 homogenized feathers, using an Advanced Mercury Analyser spectrophotometer (Altec AMA 254, detection limit of $0.05 \mathrm{ng}$ ). The analysis of each pooled sample was repeated 2 to 3 times until the relative standard deviation for 2 subsamples was $<10 \%$. Mean $[\mathrm{Hg}]$ for these 2 subsamples was then used for statistical analyses. Prior to $\mathrm{Hg}$ analyses, blanks were run and, to ensure the accuracy of measurements, certified reference materials from the National Research Council of Canada (NRC) were used every 15 samples. The reference materials were lobster hepatopancreas TORT-3 (reference vs. measured mean \pm SD: $0.29 \pm 0.02$ vs. $0.30 \pm 0.002 \mu \mathrm{g} \mathrm{g}^{-1} \mathrm{dw}$, recovery $=102.0 \pm 1.5 \%$ ) and lobster hepatopancreas TORT-2 (reference vs. measured: $0.27 \pm 0.06$ vs. $0.26 \pm 0.01 \mu \mathrm{g} \mathrm{g}^{-1} \mathrm{dw}$, recovery $=$ $97.3 \pm 1.0 \%)$. 


\subsection{Statistical analyses}

Variations in $[\mathrm{Hg}]$ in the different species were analyzed as a function of seabird fidelity to a wintering ground. To do so, the difference in $[\mathrm{Hg}]$ between winters (i.e. $\Delta[\mathrm{Hg}]$ ) as well as the distance (in $\mathrm{km}$ ) between individual winter median positions was determined at the individual scale. As some individuals were tracked in 2 non-consecutive years, the variations $(\Delta[\mathrm{Hg}]$ and distance) were studied for winter $_{t}-$ winter $_{t+1}$, winter $_{t}-$ winter $_{t+2}$, winter $_{t+1}-$ winter $_{t+2}$. Phillips et al. (2004) showed that the accuracy of seabird positions using light level geolocators is $186 \pm 114$ (SD) km. Given this accuracy and the scale of the study area, we considered the limit of $372 \mathrm{~km}$ to discriminate between high or low fidelity to a wintering ground, despite the fact that the different study species can be more or less mobile during winter. Based on this limit, differences between 2 winter median positions $<372 \mathrm{~km}$ apart were classified as 'high fidelity', whereas winter median positions $\geq 373 \mathrm{~km}$ apart were considered to belong to the 'low fidelity' group. To ensure the defined threshold of $372 \mathrm{~km}$ did not significantly affect our results and conclusions, the same analyses were performed using thresholds of 200, 300, 350, 450 and $500 \mathrm{~km}$ (Table S5 in the Supplement).

First, we tested $[\mathrm{Hg}]$ differences among species using linear mixed models (LMMs) (R package 'lme4') (Bates et al. 2015). To take into account the non-independence in our data (i.e. repeated $\Delta[\mathrm{Hg}]$ measures for 36 individuals), we included the bird identity (i.e. Bird ID) as a random factor, with the full model being $[\mathrm{Hg}] \sim$ species $+(1 \mid$ Bird ID). Then, we performed LMMs to investigate differences in $\Delta[\mathrm{Hg}]$ (using absolute values, i.e. ignoring the signs) between low- and high-fidelity groups and species. To take into account the non-independence in our data (i.e. repeated $\Delta[\mathrm{Hg}]$ measures for 36 individuals), we included the bird identity (i.e. Bird ID) as a random factor. The full model (see LMM1 in Table 2) was: $\Delta[\mathrm{Hg}] \sim$ fidelity (low/high) * species + (1| Bird ID). We used a square root transformation for $\Delta[\mathrm{Hg}]$ to meet the parametric assumptions of normality and homoscedasticity of residual distribution.

In a second step, we considered the low-fidelity group only and used the longitude and latitude of seabird winter median positions during the different winters to determine the direction from the previous to the newly used wintering ground (northwest, northeast, southwest or southeast). As we were interested in the direction of migration and its influence on the increase or decrease in $\Delta[\mathrm{Hg}]$, we used $\Delta[\mathrm{Hg}]$ raw values (i.e. considering the signs) for this analysis. Therefore, we used LMMs to test if $\Delta[\mathrm{Hg}]$ varied depending on overwintering area (i.e. direction), migration distances (in $\mathrm{km}$ ) and species. The individual identity was added as a random effect to take into account the non-independence in our data (i.e. repeated $\Delta[\mathrm{Hg}]$ measures). The full model was (see LMM2 in Table 2): $\Delta[\mathrm{Hg}] \sim$ direction (northwest, northeast, southwest or southeast) $*$ species + distance (in $\mathrm{km}) *$ species $+(1 \mid$ Bird ID). Residuals from this model were normally distributed and homoscedastic; thus, no transformation of $\Delta[\mathrm{Hg}]$ was needed. The common eiders were not added to this analysis as all individuals showed high fidelity to their wintering grounds. We used the Akaike's information criterion (AIC) to select the best model (Burnham \& Anderson 2002). If the difference in AIC between 2 models is $<2$, the models are considered to have equal statistical support. All statistical analyses were performed with $\mathrm{R}$ version 4.0.3 and RStudio version 1.3.1093 (R Core Team 2017). Data are reported as mean \pm SD unless otherwise noted.

\section{Results}

Our results indicated differences in $[\mathrm{Hg}]$ among species $\left(F_{5,188.19}=18.156, \mathrm{p}<0.001\right)$. Brünnich's guillemots showed the highest raw mean concentrations $\left(4.09 \pm 2.24 \mu \mathrm{g} \mathrm{g}{ }^{-1} \mathrm{dw}\right)$, although similar to those measured in black-legged kittiwakes $(\mathrm{LMM}, \mathrm{p}=0.23)$ and little auks $(\mathrm{p}=$ 0.44). Common guillemots and northern fulmars showed intermediate raw mean concentrations, and common eiders had the lowest raw mean $[\mathrm{Hg}]\left(0.81 \pm 0.29 \mu \mathrm{g} \mathrm{g}^{-1} \mathrm{dw}\right)$ (Table 1, Fig. S3 in the Supplement). 
Our results indicate that $\Delta[\mathrm{Hg}]$ varied between species and in response to fidelity (i.e. low or high) to their wintering ground. Indeed, our model selection indicates that the best model included these 2 variables without interaction (Table 2), with the variation of $\Delta[\mathrm{Hg}]$ impacted by the species and their fidelity to a wintering ground. More specifically, the $\Delta[\mathrm{Hg}]$ decreased from low (intercept $\pm \mathrm{SE}=1.11 \pm 0.12 \mu \mathrm{g} \mathrm{g}^{-1} \mathrm{dw}$ ) to high fidelity (estimate $\pm \mathrm{SE}=0.97 \pm 0.06 \mu \mathrm{g} \mathrm{g}^{-1} \mathrm{dw}$ ). The lack of interaction between fidelity and species suggests that the difference between low and high fidelity is the same for all species, except common eiders, which only present individuals with high fidelity to a wintering ground (Table 1, Figs. $3 \&$ S4). Seabirds with low fidelity to a wintering ground presented higher variation of $\Delta[\mathrm{Hg}]$ than seabirds with high fidelity. Compared to the model selection considering $372 \mathrm{~km}$ as a threshold, factors possibly explaining [Hg] were different when considering thresholds below $372 \mathrm{~km}$ (i.e. $200,300,350 \mathrm{~km}$ ). Indeed, the model selection showed 2 models with a $\triangle \mathrm{AIC}<2$, one with both 'fidelity' and 'species', and one with 'species' only. However, model selection was similar when considering thresholds higher than $372 \mathrm{~km}$ (i.e. $450,500 \mathrm{~km}$ ) (Table S4). This supports the use of $372 \mathrm{~km}$ as a threshold between high and low winter ground fidelity. Blacklegged kittiwakes, common guillemots and little auks were equally presented in the groups of low and high fidelity to a wintering ground between 2 years. Most of the Brünnich's guillemot distributions corresponded to high fidelity to a wintering ground, while most of the northern fulmar distributions fell in the low-fidelity group (Table 1).

Within the low-fidelity group, results indicated that 2 models had a $\triangle \mathrm{AIC}<2$ (Table 2). Both models showed that $\Delta[\mathrm{Hg}]$ varied with migration direction, migration distance and among species. $\Delta[\mathrm{Hg}]$ variation was the highest when individuals changed their winter distribution to the northwest direction and the lowest when individuals changed to the southeast direction, and these effects were similar among species (i.e. interaction between direction and species was not selected in the model with the lowest AIC; Figs. 4, S5 \& S6, Table 2). Additionally, $\Delta[\mathrm{Hg}]$ decreased when individuals increased the distance from their previous wintering ground, and this effect was similar among direction and species (i.e. interaction between direction or species was not selected in the model with the lowest AIC Table 2). Including the interaction between distance and species decreased the AIC by 1.34 , suggesting that the distance effect slightly varied among species (Fig. S6).

\section{Discussion}

Seabirds can adopt different non-breeding strategies and show contrasting fidelity to their wintering site, at species, population and individual scales (Hatch et al. 2010, McFarlane Tranquilla et al. 2014, Orben et al. 2015, Hanssen et al. 2016, Merkel et al. 2020). Hence, while some seabirds use the same wintering ground every year, others change and occupy different places from one year to the other. Such different strategies can have large effects on their exposure to environmental stressors, particularly pollutants, which could in turn impact their contamination level, body condition, reproduction and ultimately their population dynamics. By combining for the first time the use of tracking devices on multiple species with $\mathrm{Hg}$ analyses, we demonstrated that inter-annual fidelity of seabirds to a wintering area affects their contamination level, with a major effect of the location of these areas in the North Atlantic and sub-Arctic.

Inter-annual changes in $\mathrm{Hg}$ contamination might be driven by several non-exclusive factors, including different diets, changing migratory strategies between years (i.e. resident vs. migrating, fidelity to their wintering site) or different regions used during winter in the North Atlantic-Arctic. $[\mathrm{Hg}]$ in Arctic seabirds, like in other predators, are closely related to their diet. For example, previous studies found that $[\mathrm{Hg}]$ increased in sub-Antarctic seabirds, from those feeding at low trophic levels (i.e. on crustaceans) to those feeding at higher trophic levels (i.e. on fish, squid and carrion consumers; Carravieri et al. 2014). During winter, common guillemots and northern fulmars generally feed on relatively high trophic levels (mainly fish; Erikstad 1990, Gaston \& Jones 1998) compared to Brünnich's guillemots, black-legged kittiwakes, little auks, (mainly zooplankton; 
Gaston \& Jones 1998, Karnovsky et al. 2008, Fort et al. 2010, Frederiksen et al. 2012, Reiertsen et al. 2014) or common eiders (bivalves; Goudie et al. 2020). Therefore, higher [Hg], if explained by diet differences only, should be expected in common guillemots and northern fulmars, followed by Brünnich's guillemots, black-legged kittiwakes, little auks and then common eiders. However, and contrary to our prediction, our results showed a different contamination pattern. Indeed, we found that the Brünnich's guillemots had the highest raw mean $[\mathrm{Hg}]$, followed by black-legged kittiwakes, little auks, common guillemots and northern fulmars being more contaminated than the common eiders (Table 1). Additionally, our results showed that $[\mathrm{Hg}]$ above $5 \mu \mathrm{g} \mathrm{g}^{-1} \mathrm{dw}$ in feathers, the threshold above which the first deleterious effects are observed in birds (Eisler 1987), were observed in variable proportions according to the species with $2 \%$ in northern fulmars, $4 \%$ in common guillemots, $15 \%$ in black-legged kittiwakes and 37\% in Brünnich's guillemots. Altogether, these results suggest an interspecies variation in $\mathrm{Hg}$ contamination and that inter-annual variations in winter $\mathrm{Hg}$ contamination cannot be explained by the diet alone, but potentially by seabird movements and distribution.

Our study focused on 6 species breeding at 17 different colonies, showing contrasting fidelity to their wintering grounds within and between species. The common eider was the only species for which all individuals showed a high fidelity to their wintering grounds, overwintering year after year in the same areas. This is the case for both eiders breeding in the Low Arctic and resident yearround, and populations from the High Arctic migrating to southernly, but constant, locations during winter (Bustnes \& Erikstad 1993, Hanssen et al. 2016). As a consequence, common eiders in this study showed similar constant and low $[\mathrm{Hg}]$ from one year to the other. The 5 other study species presented low or high inter-annual fidelity to their wintering grounds (Table 1). Accordingly, seabirds with low inter-annual fidelity had a slightly higher $\Delta[\mathrm{Hg}]$ mean than seabirds with high inter-annual fidelity (Figs. $3 \&$ S4), confirming an effect of adopted migratory movements on seabird winter $\mathrm{Hg}$ contamination, and suggesting spatial variations over the North Atlantic-Arctic.

In addition, when experiencing low fidelity to a wintering ground, we found that while the effect of the direction was similar between species, the effect of the distance was not. More specifically, regardless of the species, our results indicated that $[\mathrm{Hg}]$ tended to increase when individuals migrated northwest of their previous wintering ground. In comparison, $[\mathrm{Hg}]$ tended to decrease when migration direction switched to the 3 other directions (Figs. 4 \& S5). We found that when the distance to the previous wintering ground increased, $\mathrm{Hg}$ concentrations decreased for common guillemots, little auks and northern fulmars, and increased for black-legged kittiwakes and Brünnich's guillemots. Overall, this supports the hypothesis of a heterogeneous distribution of $\mathrm{Hg}$ in the marine environment at large spatial scale. In the present study, wintering Brünnich's guillemots and northern fulmars covered a large part of the North Atlantic, while common guillemots, blacklegged kittiwakes and little auks were distributed over a part of it only (Figs. 1 \& S1). With such a large-scale study, seabirds found on the eastern (or western) areas for the first year of our assessment had more chance to migrate in the western (or eastern) areas the following years and such a point was not possible to incorporate into the statistical analysis. But despite these spatial differences, our results showed that seabird $[\mathrm{Hg}]$ varied the same way between years according to changes in their distribution and directions, strengthening our interpretation. We therefore think that our results confirm the role of seabird winter movements and distribution on their contamination to $\mathrm{Hg}$ and highlight spatial differences in $[\mathrm{Hg}]$ through the North Atlantic-Arctic, with an increasing east-west gradient. Previous studies on the Arctic wildlife also suggested a positive east-west $\mathrm{Hg}$ gradient during spring and summer (breeding period), with species distributed in the Canadian Arctic being more contaminated than those in the European Arctic (Provencher et al. 2014, AMAP 2018, Albert et al. 2019). The present data set covers a large but fragmented part of the North Atlantic-Arctic. But a more precise dataset could allow us to confirm and extend such a trend in the North AtlanticArctic. 
Seabirds are exposed to various environmental threats during the winter period (e.g. oil spills, storms, contaminants; Frederiksen et al. 2012, Petersen et al. 2012, Fort et al. 2014, Guéry et al. 2017) which might impact their condition, survival or subsequent reproduction (Votier et al. 2005, Mesquita et al. 2015, Anker-Nilssen et al. 2016). The large-scale distribution of $\mathrm{Hg}$ in the marine environment is assumed to be relatively stable over years (Mason et al. 1998). Hence, high fidelity to their wintering ground likely expose seabirds to repeated threats and constant pollution issues associated to this specific area (e.g. human industries), possibly impacting their short-term survival and reproduction with long-term impacts on their population dynamics (Guéry et al. 2017, 2019). Conversely, seabirds with low fidelity to a wintering ground and winter distribution will exploit contrasting wintering environments with different $[\mathrm{Hg}]$ year after year (Quillfeldt et al. 2010) which might lower long-term risks associated with $\mathrm{Hg}$ contamination. On the other hand, seabirds wintering consistently in an area with low levels of such threats might nonetheless only be exposed to limited acute pollution events, with limited short-term and long-term impacts on their populations. Therefore, the inter-individual variability in $[\mathrm{Hg}]$ dependent on winter-ground fidelity should be taken into account while studying population dynamics in migratory species, as it could have large effects on their survival, reproduction and subsequently on the population dynamics.

Our study demonstrates that individual migratory strategy and the consistency of occupied wintering grounds affect their contamination with $\mathrm{Hg}$. Given the high diversity of areas used by single individuals over 2 to 3 winters only, we urge to extend ecotoxicological studies investigating seabird winter contamination and its impacts in order to consider these inter-annual variations and fully apprehend the risks that $\mathrm{Hg}$ and other pollutants represent for seabirds and other marine organisms.

\section{Acknowledgments.}

This study is part of several research programs supported by the French Agency for National Research (MAMBA project ANR-16-TERC-0004, ILETOP project ANR-16-CE34-0005, ARCTICSTRESSORS project ANR-20-CE34-0006), the French Arctic Initiative - CNRS (PARCS project), the Mission pour l'Interdisciplinarite - CNRS (Changements en Siberie project), the French Polar Institute (IPEV - Pgr 388 ADACLIM) and the European Commission (Marie Curie CIG, Project 631203). This work was supported by a grant (232019) from the Fram Center flagship 'Climate Change in Fjord and Coast' to B.M. The IUF (Institut Universitaire de France) is also acknowledged for its support to P.B. as a Senior Member. C.A. was supported by a $\mathrm{PhD}$ fellowship from the French Ministry of Higher Education and Research. Thanks to the CPER (Contrat de Projet Etat-Region) and the FEDER (Fonds Europeen de Developpement Regional) for funding the AMA (Advanced Mercury Analyser) and the IRMS (Isotope-Radio Mass Spectrometry) of LIENSs laboratory. We thank the plateforme analytique of the Institut du Littoral, Environnement et Societes (LIENSs) and Maud Brault-Favrou for the technical support with the Hg analyses. Fieldwork on Eynhallow was conducted under permits from the British Trust for Ornithology for catching and instrumenting fulmars, and the UK Home Office for feather sampling. We thank Orkney Islands Council for access to this colony. The deployment and retrieval of GLS loggers and sampling of feathers were conducted as part of the SEATRACK project (www.seapop.no/ en/ seatrack/) in northern Europe (Norwegian and UK colonies), made possible through close cooperation with the SEAPOP program (www.seapop.no, Norwegian Research Council grant \#192141) and ARCTOX network (https://arctox. cnrs.fr). We are grateful to Jonathan A. Green and 2 anonymous reviewers for their comments that greatly improved the initial manuscript.

\section{Literature Cited}

Ackerman JT, Eagles-Smith CA, Herzog MP, Hartman CA and others (2016) Avian mercury exposure and toxicological risk across western North America: a synthesis. Sci Total Environ 568:749-769 
Agusa T, Matsumoto T, Ikemoto T, Anan Y and others (2005) Body distribution of trace elements in blacktailed gulls from Rishiri Island, Japan: age-dependent accumulation and transfer to feathers and eggs. Environ Toxicol Chem 24:2107-2120

Albert C, Renedo M, Bustamante P, Fort J (2019) Using blood and feathers to investigate large-scale Hg contamination in Arctic seabirds: a review. Environ Res 177: 108588 AMAP (Arctic Monitoring and Assessment Programme) (2011)

AMAP assessment 2011: mercury in the Arctic. AMAP, Oslo. www.amap.no/documents/download/989/ inline

AMAP (2018) AMAP assessment 2018: biological effects of contaminants on Arctic wildlife and fish. AMAP, Tromso. www.amap.no/documents/download/3080/inline

Anker-Nilssen T, Harris MP, Kleven O, Langset M (2017) Status, origin, and population level impacts of Atlantic puffins killed in a mass mortality event in southwest Norway early 2016. Seabird 30:1-14

Atwell L, Hobson KA, Welch HE (1998) Biomagnification and bioaccumulation of mercury in an arctic marine food web: insights from stable nitrogen isotope analysis. Can J Fish Aquat Sci 55:1114-1121

Baldassarre G (2014) Ducks, geese and swans of North America. Wildlife Management Institute, Johns Hopkins University Press, Baltimore, MD

Bates D, Machler M, Bolker B, Walker S (2015) Fitting Linear Mixed-Effects Models using lme4. J Stat Soft 67(1): $1-48$

Brathen VS, Moe B, Amelineau F, Ekker M and others (2021) An automated procedure (v2.0) to obtain positions from light-level geolocators in large-scale tracking of seabirds. A method description for the SEATRACK project. NINA Report 1893. Norwegian Institute for Nature Research, Trondheim. https://brage.nina.no/nina-xmlui/handle/11250/2735757

Braune BM (1987) Comparison of total mercury levels in relation to diet and molt for nine species of marine birds. Arch Environ Contam Toxicol 16:217-224

Burnham KP, Anderson DR (2002) Model selection and multi-model inference: a practical informationtheoretic approach. Springer, New York, NY

Bustnes JO, Erikstad KE (1993) Site fidelity in breeding common eider Somateria mollissima females. Ornis Fenn 70:11-16

Carravieri A, Cherel Y, Blevin P, Brault-Favrou M, Chastel O, Bustamante P (2014) Mercury exposure in a large subantarctic avian community. Environ Pollut 190:51-57

Cherel Y, Barbraud C, Lahournat M, Jaeger A and others(2018) Accumulate or eliminate? Seasonal mercury dynamics in albatrosses, the most contaminated family of birds. Environ Pollut 241:124-135

Cramp S, Simmons KEL (1983) Handbook of the birds of Europe, the Middle East and North Africa. The birds of the Western Palearctic. Vol III. Waders to gulls. Oxford University Press, Oxford

Croxall JP, Butchart SHM, Lascelles B, Stattersfield AJ, Sullivan B, Symes A, Taylor P (2012) Seabird conservation status, threats and priority actions: a global assessment. Bird Conserv Int 22:1-34

Delord K, Cherel Y, Barbraud C, Chastel O, Weimerskirch H (2018) High variability in migration and wintering strategies of brown skuas (Catharacta antarctica lonnbergi) in the Indian Ocean. Polar Biol 41:59-70

Dietz R, Riget F, Born EW (2000) Geographical differences of zinc, cadmium, mercury and selenium in polar bears (Ursus maritimus) from Greenland. Sci Total Environ 245:25-47

Dietz R, Sonne C, Basu N, Braune B and others (2013) What are the toxicological effects of mercury in Arctic biota? Sci Total Environ 443:775-790

Dietz R, Letcher RJ, Desforges JP, Eulaers I and others (2019) Current state of knowledge on biological effects from contaminants on arctic wildlife and fish. Sci Total Environ 696:133792

Egevang C, Stenhouse IJ, Phillips RA, Petersen A, Fox JW, Silk JRD (2010) Tracking of Arctic terns Sterna paradisaea reveals longest animal migration. Proc Natl Acad Sci USA 107:2078-2081

Eisler R (1987) Mercury hazards to fish, wildlife and invertebrates: a synoptic review. Contaminant Hazard Reviews Report 10. US Fish Wildl Serv Biol Rep 85(1.10)

Erikstad KE (1990) Winter diets of four seabird species in the Barents Sea after a crash in the capelin stock. Polar Biol 10:619-627

Fleishman AB, Orben RA, Kokubun N, Will A, Paredes R and others (2019) Wintering in the Western Subarctic Pacific Increases mercury contamination of red-legged kittiwakes. Environ Sci Technol 53:13398-13407 
Fort J, Cherel Y, Harding AMA, Welcker J and others (2010) Geographic and seasonal variability in the isotopic niche of little auks. Mar Ecol Prog Ser 414:293-302

Fort J, Beaugrand G, Gremillet D, Phillips RA (2012) Biologging, remotely-sensed oceanography and the continuous plankton recorder reveal the environmental determinants of a seabird wintering hotspot. PLOS ONE 7:e41194

Fort J, Moe B, Strom H, Gremillet D and others (2013a) Multi colony tracking reveals potential threats to little auks wintering in the North Atlantic from marine pollution and shrinking sea ice cover. Divers Distrib 19:1322-1332

Fort J, Steen H, Strom H, Tremblay Y and others (2013b) Energetic consequences of contrasting winter migratory strategies in a sympatric Arctic seabird duet. J Avian Biol 44:255-262

Fort J, Robertson GJ, Gremillet D, Traisnel G, Bustamante P (2014) Spatial ecotoxicology: Migratory Arctic seabirds are exposed to mercury contamination while overwintering in the Northwest Atlantic. Environ Sci Technol 48:11560-11567

Frederiksen M, Moe B, Daunt F, Phillips RA and others (2012) Multicolony tracking reveals the winter distribution of a pelagic seabird on an ocean basin scale: winter distribution of Atlantic kittiwakes. Divers Distrib 18:530-542

Frederiksen M, Descamps S, Erikstad KE, Gaston AJ and others (2016) Migration and wintering of a declining seabird, the thick-billed murre Uria lomvia, on an ocean basin scale: conservation implications. Biol Conserv 200: 26-35

Gaston AJ, Jones IL (1998) The auks: Alcidae. Bird families of the world. Oxford University Press, Oxford

Goudie RI, Robertson GJ, Reed A (2020) Common eider (Somateria mollissima), version 1.0. In: Billerman SM (ed) Birds of the world. https://birdsoftheworld.org/ bow/species/comeid/cur/introduction (accessed April 2020)

Goutte A, Bustamante P, Barbraud C, Delord K, Weimerskirch H, Chastel O (2014) Demographic responses to mercury exposure in two closely related antarctic top predators. Ecology 95:1075-1086

Grissot A, Graham IM, Quinn L, Brathen VS, Thompson PM (2020) Breeding status influences timing but not duration of moult in the Northern fulmar Fulmarus glacialis. Ibis 162:446-459

Grist H, Daunt F, Wanless S, Nelson EJ and others (2014) Site fidelity and individual variation in winter location in partially migratory European shags. PLOS ONE 9:e98562

Guery L, Descamps S, Pradel R, Hanssen SA and others (2017) Hidden survival heterogeneity of three common eider populations in response to climate fluctuations. J Anim Ecol 86:683-693

Guery L, Descamps S, Hodges KI, Pradel R and others (2019) Winter extratropical cyclone influence on seabird survival: variation between and within common eider Somateria mollissima populations. Mar Ecol Prog Ser 627:155-170

Guilford T, Freeman R, Boyle D, Dean B, Kirk H, Phillips R, Perrins C (2011) A dispersive migration in the Atlantic puffin and its implications for migratory navigation. PLOS ONE 6:e21336

Hanssen SA, Gabrielsen GW, Bustnes JO, Brathen VS and others (2016) Migration strategies of common eiders from Svalbard: implications for bilateral conservation management. Polar Biol 39:2179-2188

Hatch SA, Gill VA, Mulcahy DM (2010) Individual and colony-specific wintering areas of Pacific northern fulmars (Fulmarus glacialis). Can J Fish Aquat Sci 67:386-400

Honda K, Nasu T, Tatsukawa R (1986) Seasonal changes in mercury accumulation in the black-eared kite, Milvus migrans lineatus. Environ Pollut A 42:325-334 Hsu-Kim H, Kucharzyk KH, Zhang T, Deshusses MA (2013) Mechanisms regulating mercury bioavailability for me thylating microorganisms in the aquatic environment: a critical review. Environ Sci Technol 47:2441-2456

Karnovsky NJ, Hobson KA, Iverson S, Hunt GL Jr (2008) Seasonal changes in diets of seabirds in the North Water Polynya: a multiple-indicator approach. Mar Ecol ProgSer 357:291-299

Lamborg CH, Hammerschmidt CR, Bowman KL, Swarr GJ and others (2014) A global ocean inventory of anthropogenic mercury based on water column measurements. Nature 512:65-68

Lisovski S, Hewson CM, Klaasen RHG, Korner-Nievergelt F, Kristensen MW, Hahn S (2012) Geolocation by light: accuracy and precision affected by environmental factors. Methods Ecol Evol 3:603-612

Macdonald MA (1980) The winter attendance of fulmars at land in NE Scotland. Ornis Scand (Scand J Ornithol) 11:23-29

Mason RP, Rolfhus KR, Fitzgerald WF (1998) Mercury in theNorth Atlantic. Mar Chem 61:37-53 
McFarlane Tranquilla LA, Montevecchi WA, Fifield DA, Hedd A, Gaston AJ, Robertson GJ, Phillips RA (2014) Individual winter movement strategies in two species of murre (Uria spp.) in the Northwest Atlantic. PLOS ONE 9:e90583

Merkel B, Phillips RA, Descamps S, Yoccoz NG, Moe B, Strom H (2016) A probabilistic algorithm to process geolocation data. Mov Ecol 4:26

Merkel B, Descamps S, Yoccoz NG, Danielsen J and others (2019) Earlier colony arrival but no trend in hatching timing in two congeneric seabirds (Uria spp.) across the North Atlantic. Biol Lett $15: 20190634$

Merkel B, Descamps S, Yoccoz NG, Gremillet D and others (2021) Individual migration strategy fidelity but no habitat specialization in two congeneric seabirds. J Biogeogr 48:263-275

Mesquita MdS, Erikstad KE, Sandvik H, Barrett RT and others (2015) There is more to climate than the North Atlantic Oscillation: a new perspective from climate dynamics to explain the variability in population growth rates of a long-lived seabird. Front Ecol Evol 3:43

Orben RA, Paredes R, Roby DD, Irons DB, Shaffer SA (2015) Wintering North Pacific black-legged kittiwakes balancespatial flexibility and consistency. Mov Ecol 3:36

Paleczny M, Hammill E, Karpouzi V, Pauly D (2015) Population trend of the world's monitored seabirds, 1950-2010. PLOS ONE 10:e0129342

Petersen MR, Douglas DC, Wilson HM, McCloskey SE (2012) Effects of sea ice on winter site fidelity of Pacific common eiders (Somateria mollissima v-nigrum). Auk 129:399-408

Phillips RA, Silk JRD, Croxall JP, Afanasyev V, Briggs DR (2004) Accuracy of geolocation estimates for flying seabirds. Mar Ecol Prog Ser 266:265-272

Provencher JF, Mallory ML, Braune BM, Forbes MR, Gilchrist HG (2014) Mercury and marine birds in Arctic Canada: effects, current trends, and why we should be paying closer attention. Environ Rev 22:244-255

Quillfeldt P, Voigt CC, Masello JF (2010) Plasticity versus repeatability in seabird migratory behaviour. Behav Ecol Sociobiol 64:1157-1164

Quinn LR, Meharg AA, van Franeker JA, Graham IM, Thompson PM (2016) Validating the use of intrinsic markers in body feathers to identify inter-individual differences in non-breeding areas of northern fulmars. Mar Biol 163:64

R Core Team (2017) R: a language and environment for statistical computing. R Foundation for Statistical Computing, Vienna. www.R-project.org/

Reiertsen TK, Erikstad KE, Anker-Nilssen T, Barrett RT and others (2014) Prey density in non-breeding areas affects adult survival of black-legged kittiwakes Rissa tridactyla. Mar Ecol Prog Ser 509:289-302

Renedo M, Amouroux D, Albert C, Berail S and others (2020) Contrasting spatial and seasonal trends of methylmercury exposure pathways of Arctic seabirds: combination of large-scale tracking and stable isotopic approaches. Environ Sci Technol 54:13619-13629

Sonke JE, Teisserenc R, Heimburger-Boavida LE, Petrova MV and others (2018) Eurasian river spring flood observations support net Arctic Ocean mercury export to the atmosphere and Atlantic Ocean. Proc Natl Acad Sci USA 115:E11586 E11594

Tan SW, Meiller JC, Mahaffey KR (2009) The endocrine effects of mercury in humans and wildlife. Crit Rev Toxicol 39:228-269

Tartu S, Angelier F, Wingfield JC, Bustamante P and others (2015) Corticosterone, prolactin and egg neglect behavior in relation to mercury and legacy POPs in a long-lived Antarctic bird. Sci Total Environ 505:180-188

UNEP (United Nations Environment Programme) (2013) Global mercury assessment 2013: sources, emissions, releases, and environmental transport. UNEP Chemicals Branch, Geneva. https://wedocs.unep.org/20.500.11822/7984

Vindenes Y, Engen S, Sather B (2008) Individual heterogeneity in vital parameters and demographic stochasticity. Am Nat 171:455-467

Votier SC, Hatchwell BJ, Beckerman A, McCleery RH and others (2005) Oil pollution and climate have wide-scale impacts on seabird demographics: guillemots, oil and climate. Ecol Lett 8:1157-1164

Wilson RP, Ducamp JJ, Rees WG, Culik BM, Niekamp K (1992) Estimation of location: global coverage using light intensity. In: Priede IG, Swift SM (eds) Wildlife telemetry: remote monitoring and tracking of animals. Ellis Horward Ltd, Chichester, p 131-134 
Wolfe MF, Schwarzbach S, Sulaiman RA (1998) Effects of mercury on wildlife: a comprehensive review. Environ Toxicol Chem 17:146-160

Zhang Y, Soerensen AL, Schartup AT, Sunderland EM (2020) A global model for methylmercury formation and uptake at the base of marine food webs. Global Biogeochem Cycles 34:e2019GB006348 
Table 1. Mercury concentrations ( $\mu \mathrm{g} \mathrm{g}-1 \mathrm{dw}$ ) in different seabird species, showing raw $[\mathrm{Hg}]$ per species (pool of wintert ,$t+1$ and $t+2$; details are summarized in Table $\mathrm{S} 1$ in the Supplement) and $|\Delta[\mathrm{Hg}]|$ (i.e. absolute values) in high and low fidelity groups (i.e. estimates extracted from the non-significant model $|\Delta[\mathrm{Hg}]| \sim$ fidelity * species $+(1 \mid$ Bird ID); see Table 2; $\Delta[\mathrm{Hg}]$ : difference in $[\mathrm{Hg}]$ between winters). The inter-annual observations (pool of wintert, $t+1$ and $t+2$ ) within high or low fidelity to a wintering ground are also indicated. ND: no data available

\begin{tabular}{|l|c|c|c|c|c|c|c|c|}
\hline Species & \multicolumn{2}{|l|}{ Raw $[\mathrm{Hg}]$} & \multicolumn{2}{|c|}{\begin{tabular}{|}
$|\Delta[\mathrm{Hg}]|$ \\
(high fidelity)
\end{tabular}} & \multicolumn{2}{|c|}{$\begin{array}{c}|\Delta[\mathrm{Hg}]| \\
\text { (low fidelity) }\end{array}$} & $\begin{array}{c}\text { Inter-annual } \\
\text { observations of } \\
\text { high fidelity }\end{array}$ & $\begin{array}{c}\text { Inter-annual } \\
\text { observations of } \\
\text { low fidelity }\end{array}$ \\
\hline & Mean $\pm \mathrm{SD}$ & $\mathrm{n}$ & Mean \pm SD & $\mathrm{n}$ & Mean $\pm \mathrm{SD}$ & $\mathrm{n}$ & & \\
\hline $\begin{array}{l}\text { Black-legged } \\
\text { kittiwakes }\end{array}$ & $3.10 \pm 1.67$ & 13 & $0.94 \pm 0.42$ & 5 & $1.13 \pm 0.42$ & 8 & 5 & 8 \\
\hline $\begin{array}{l}\text { Brünnich's } \\
\text { guillemots }\end{array}$ & $4.09 \pm 2.24$ & 65 & $0.90 \pm 0.41$ & 47 & $1.02 \pm 0.40$ & 25 & 67 & 32 \\
\hline Common eiders & $0.81 \pm 0.29$ & 22 & $0.47 \pm 0.42$ & 22 & $\mathrm{ND}$ & $\begin{array}{l}\mathrm{N} \\
\mathrm{D}\end{array}$ & 22 & 0 \\
\hline $\begin{array}{l}\text { Common } \\
\text { guillemots }\end{array}$ & $2.73 \pm 1.18$ & 39 & $0.74 \pm 0.39$ & 24 & $0.99 \pm 037$ & 21 & 31 & 30 \\
\hline Little auks & $2.93 \pm 1.23$ & 6 & $1.06 \pm 0.43$ & 3 & $0.97 \pm 0.43$ & 3 & 3 & 3 \\
\hline $\begin{array}{l}\text { Northern } \\
\text { fulmars }\end{array}$ & $2.34 \pm 1.16$ & 38 & $0.84 \pm 0.41$ & 17 & $0.91 \pm 0.40$ & 25 & 20 & 32 \\
\hline
\end{tabular}




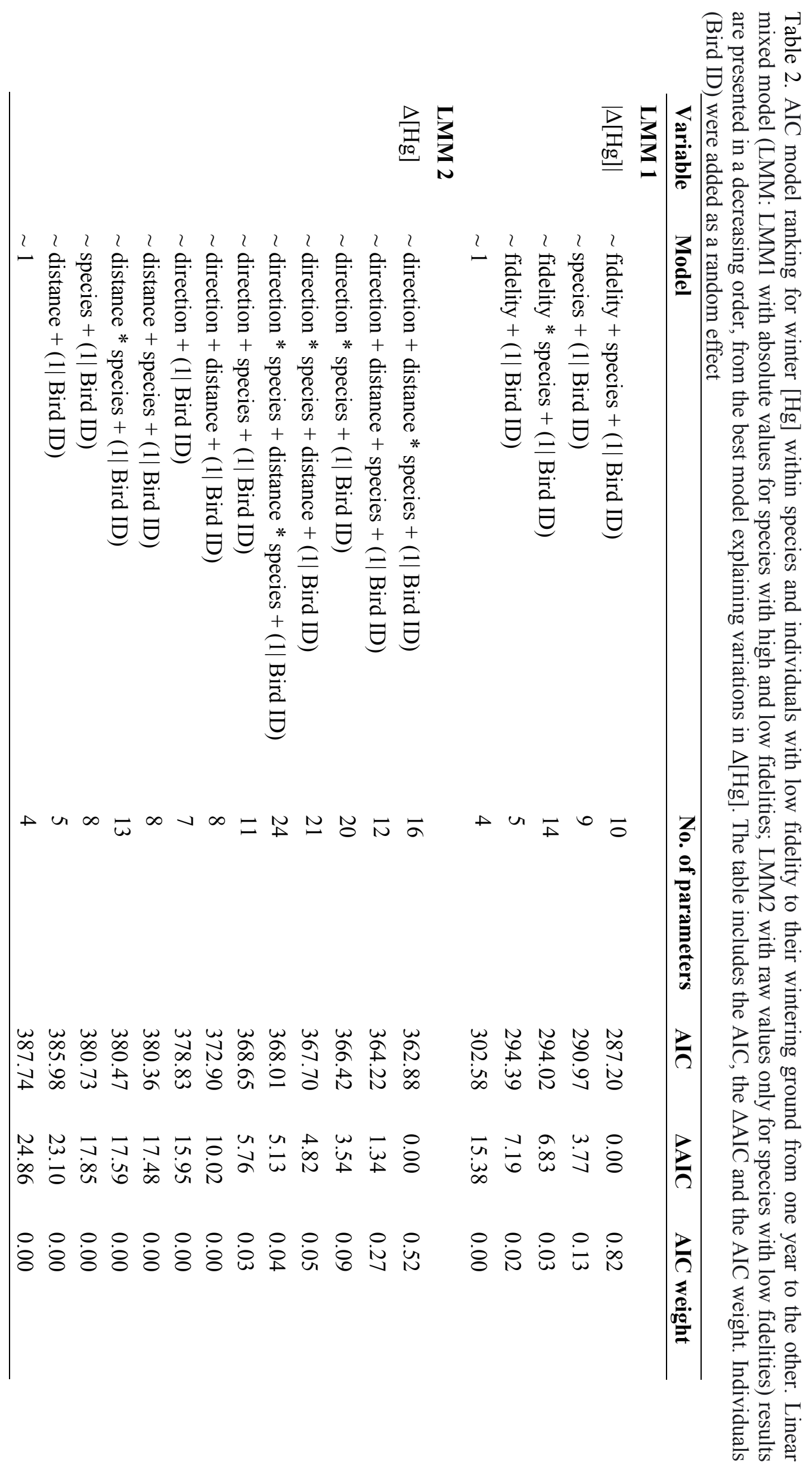




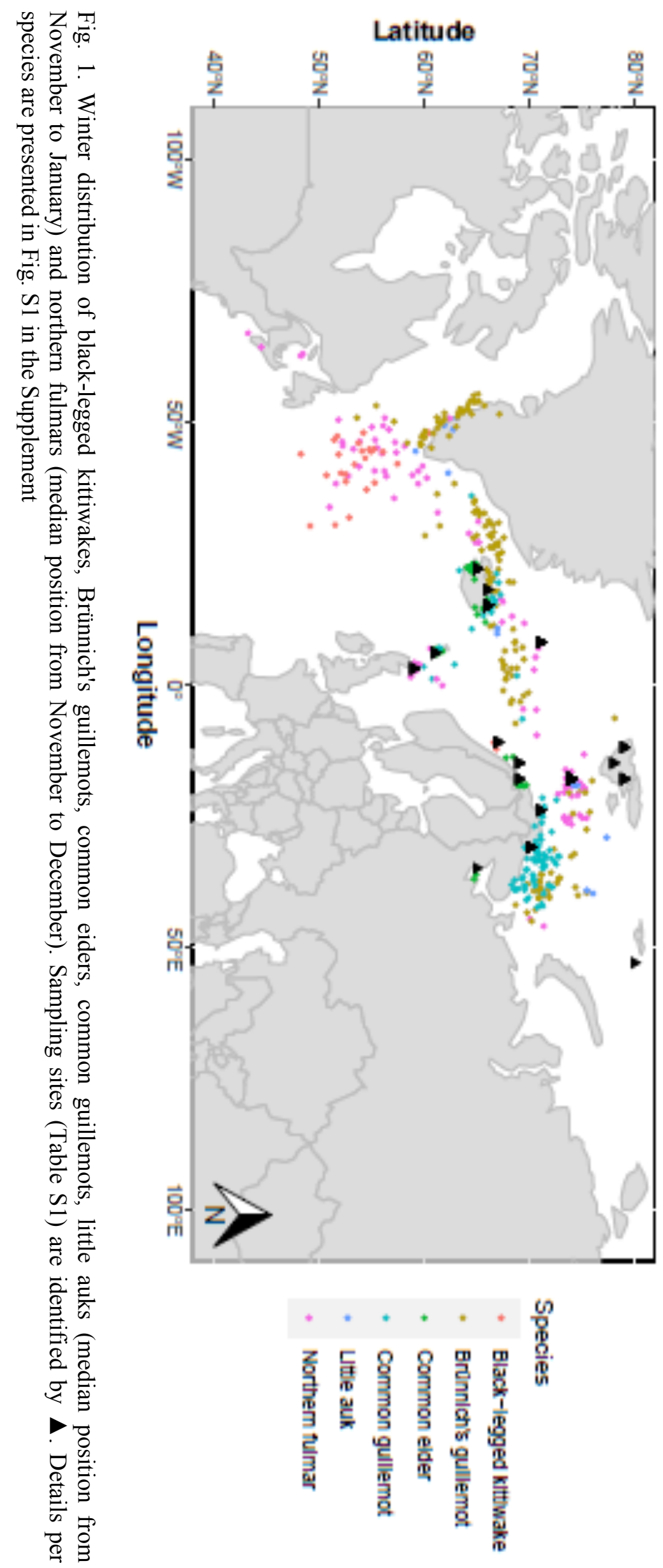




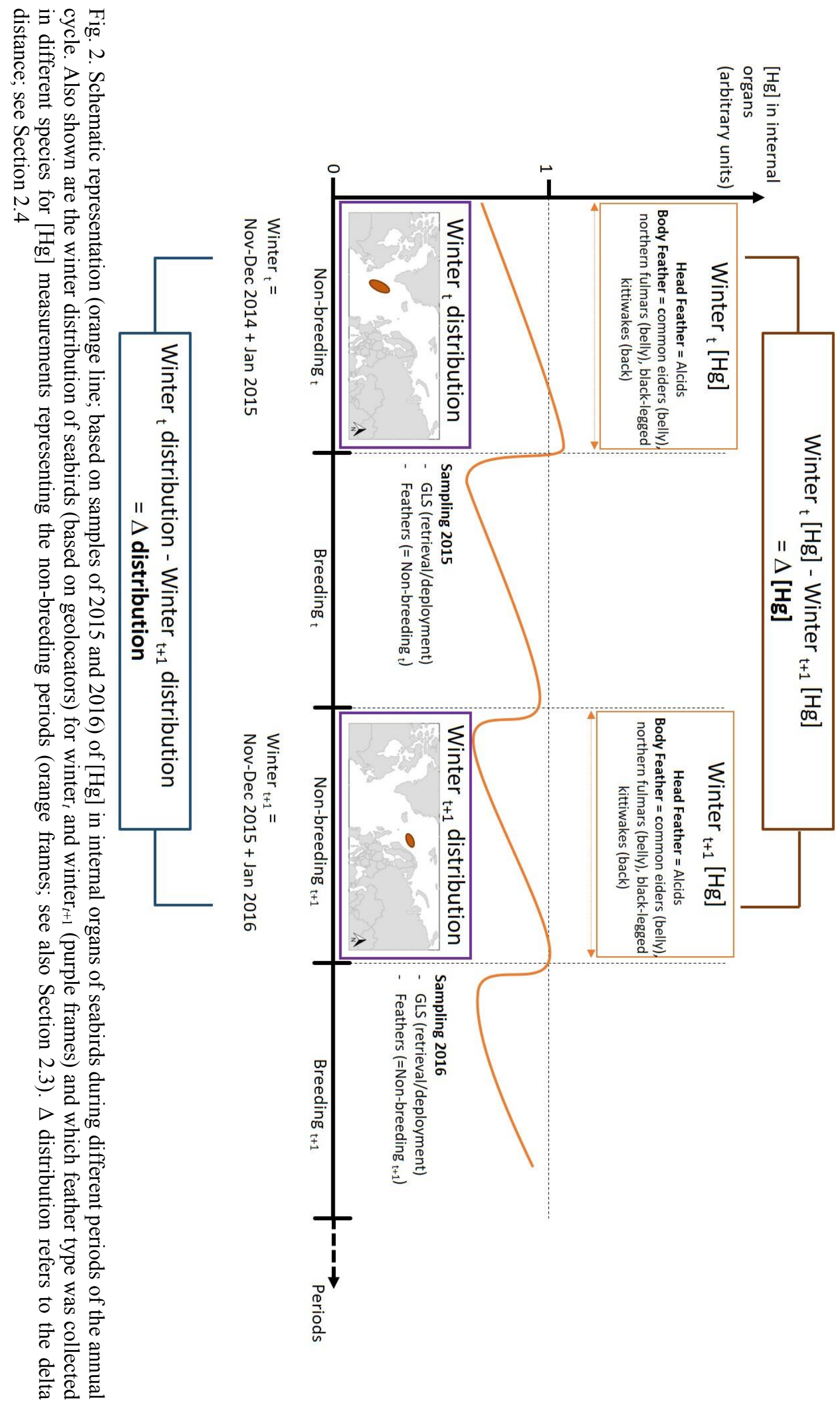




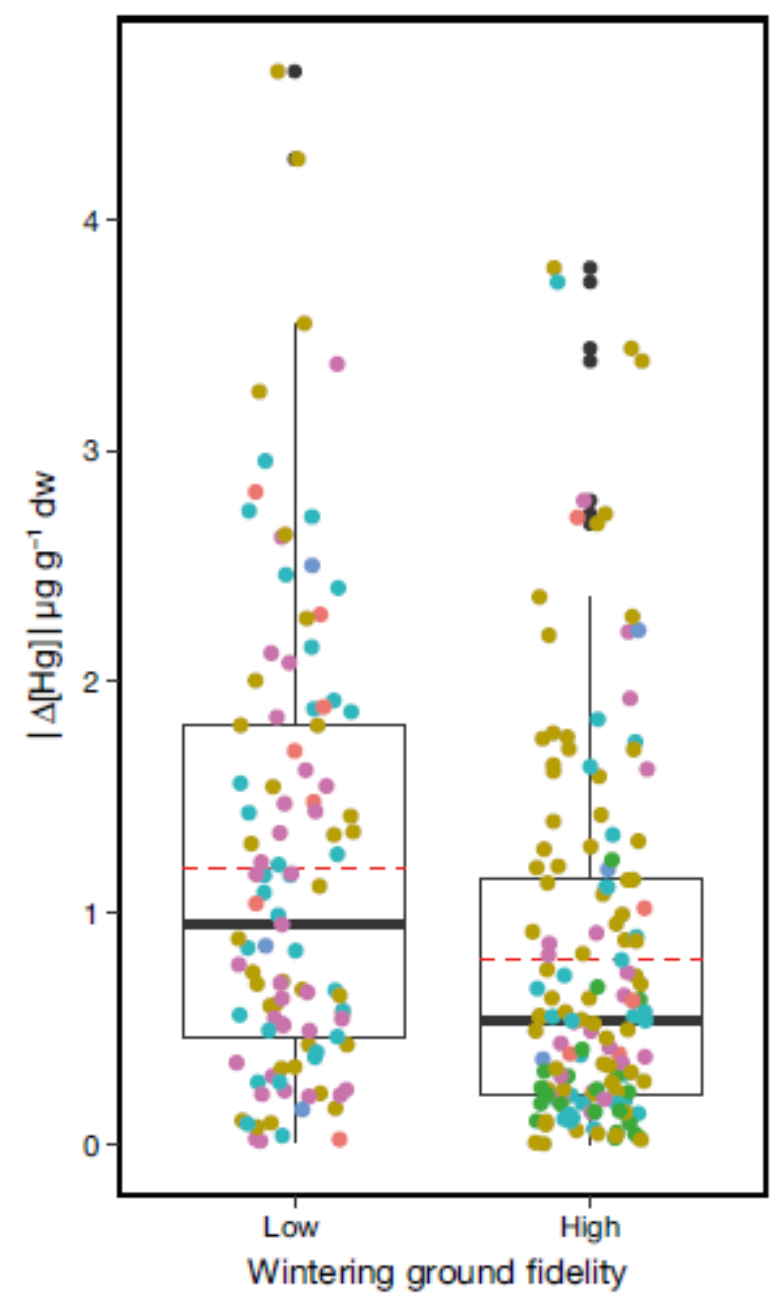

Fig. 3. $\Delta[\mathrm{Hg}]$ (absolute values; see Section 2.4) between one year and the other for seabirds with low ( $\geq 372 \mathrm{~km}$ between winter median positions in different years) or high fidelity $(<372 \mathrm{~km})$ to their wintering grounds. Red dashed line: mean (see Fig. S3 for boxplots per species). Boxplots show the median (horizontal black line within the boxes), 1st and $3^{\text {rd }}$ quartiles (Q1 and Q3), the minimum (Q1 $1.5 \times$ interquartile range) and maximum $(\mathrm{Q} 3+1.5 \times$ interquartile range) concentrations (whiskers). Outliers are represented by the black dots 


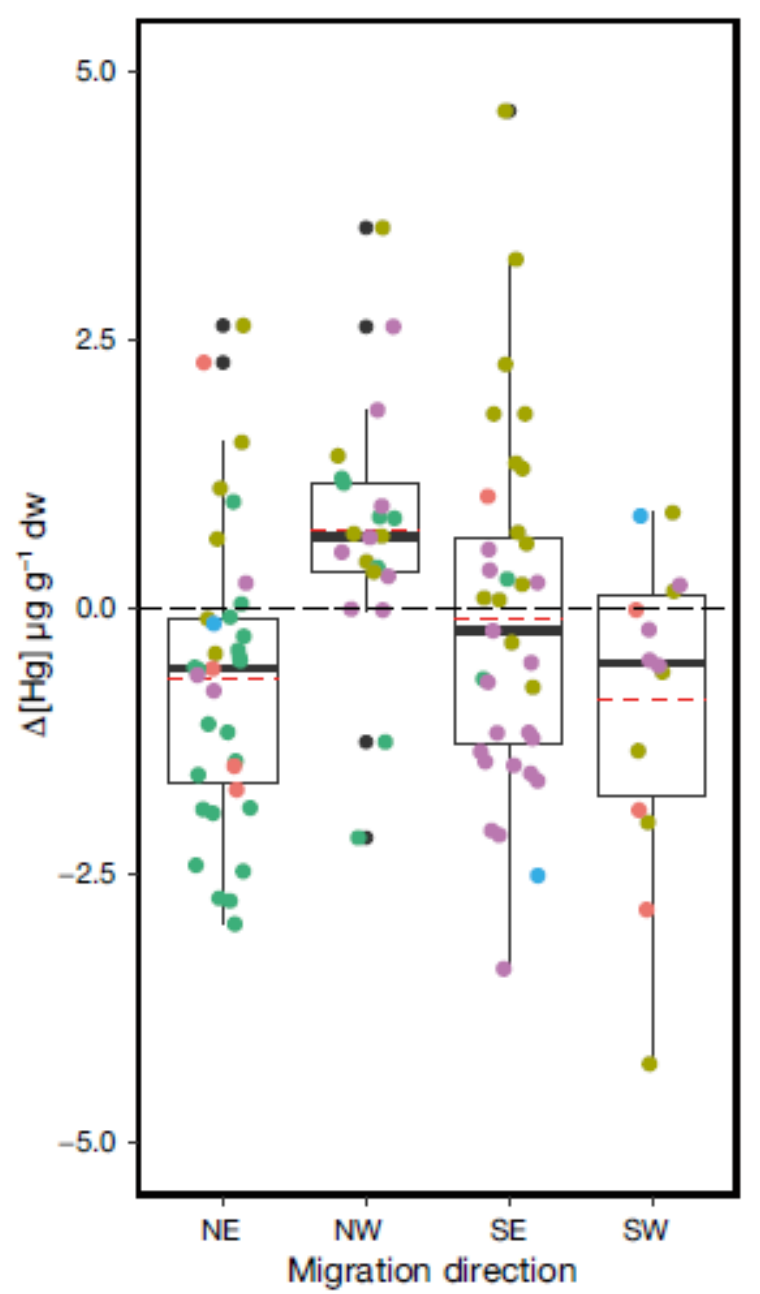

Fig. 4. $\Delta[\mathrm{Hg}]$ in relation to migration direction (direction from the previous to the newly used wintering ground) for species with low inter-annual fidelity to their wintering ground. NE: northeast, NW: northwest, SE: southeast, SW: southwest; red dashed line: mean (see Fig. S4 for boxplots per species); black dashed line: zero axis. Boxplots as in Fig. 3 